\title{
PENGARUH PROGRAM ANTI KEMISKINAN DAN PENINGKATAN PENDAPATAN PETANI (STUDI KASUS DI KELOMPOK TANI KARYA MAKMUR KABUPATEN PACITAN)
}

\author{
Danny Bastian \\ Badan Perencana Pembangunan Provinsi (BAPPEPROV) Jawa Timur
}

\begin{abstract}
This research is aimed at analyzing: (1) farmer's perception towards initiating Anti Poverty Program-APP (2) the difference in farmers' income before and after accepting the Program (3) Internal and external influencing factors to achieve the program's goal. It was found that (1) farmers had positive response towards the Program. Most farmers agreed that the program had increased their production even though some still said no. (2) There was an increase in farmers' income as large as $21.03 \%$ growth after experiencing in APP. (3) Strategy adopted significantly influenced the way it reached the goal. Aggressive strategy was applied by utilizing all strengthening factors internally and externally. It was recommended that the Karya Makmur farmer group in Pacitan Region ought to improve farmers self-reliance through guidance and counseling, to develop partnership in agro industrial activities for increasing production and income, to utilize the advantage of soft-loan.
\end{abstract}

Keywords: farmer's perception, Anti Poverty Program, self-reliance, partnership, soft-loan

\section{A. LATAR BELAKANG}

Jumlah penduduk miskin di Jawa Timur mengalami penurunan, pada tahun 2004 jumlah penduduk miskin sebanyak $19,10 \%$ bila dibandingkan dengan tahun 2003 yaitu sebanyak $19,52 \%$ maka tahun 2004 berkurangnya belum signifikan bila dibandingkan dengan berbagai upaya yang dilakukan oleh Pemerintah Propinsi Jawa Timur. Sementara program-program penanganan kemiskinan yang ada kurang efektif dan kelompok sasaran yang ada masih menunjukkan ketergantungan bantuan yang tinggi serta penekanan program yang ada belum mampu membangun jaringan (network/lingkages) antar usaha baik horizontal maupun vertikal, sehingga tidak mendorong keberlanjutan (less economic incentives) dan program yang diusulkan belum mendorong kegiatan ekonomi produktif masyarakat.

Inisiasi Anti Poverty Program (program anti kemiskinan) pada prinsipnya bukanlah merupakan redesign dari Gerdu-Taskin, tetapi adalah revitalisasi dari salah satu aspek tridaya dalam Gerdutaskin yaitu pemberdayaan usaha. Anti Poverty Program merupakan gagasan untuk percepatan Gerdu-Taskin dengan sasaran penduduk miskin pada satu kawasan yang berpotensi untuk pengembangan kegiatan ekonomi produktif dengan disertai pendampingan bagi masyarakat penerima bantuan. Oleh karena itu studi ini berusaha untuk mengevaluasi persepsi serta dampak dari program tersebut baik terhadap produksi maupun pendapatan petani yang terlibat di dalamnya. 


\section{Journal of Indonesian Applied Economics Vol. 3 No. 2 Oktober 2009, 121-134}

\section{B. KAJIAN TEORITIS}

Anti Poverty Program merupakan gagasan sebagai untuk mempercepat Gerdu-Taskin dengan sasaran penduduk miskin pada satu kawasan yang berpotensi untuk pengembangan kegiatan ekonomi produktif dengan disertai pendampingan bagi masyarakat penerima bantuan. Tujuan umum Anti Poverty Program (APP) adalah mengentaskan penduduk miskin dari kehidupan di bawah garis kemiskinan, melalui pemberdayaan usaha kelompok Masyarakat miskin dengan pola kemitraan yang berbasis cluster. Sedangkan tujuan khususnya adalah sebagai berikut :

a. Meningkatkan peran serta masyarakat secara aktif dalam pengambilan keputusan pembangunan secara transparan, demokratis dan bertanggung jawab

b. Mengembangkan kemampuan dan peluang usaha dalam rangka peningkatan pendapatan dan kesejahteraan bagi kelompok masyarakat miskin

c. Mengembangkan kelompok masyarakat miskin yang berpotensi melalui usaha produktif yang berbasis cluster dan dapat menjual produknya ke mitra usaha

d. Menyediakan sarana dan prasarana produksi yang mendukung pertumbuhan ekonomi kelompok masyarakat miskin yang berpotensi

Adapun sasaran lokasi adalah Kelompok masyarakat miskin yang berpotensi untuk dapat dikembangkan melalui usaha ekonomi produktif berbasis cluster, yang produknya dapat dijual kepada Mitra Usaha dalam rangka peningkatan pendapatan kelompok masyarakat miskin Sedangkan sasaran kegiatan ekonomi produktif masyarakat yang dapat mendorong penciptaan lapangan kerja, memiliki keberlanjutan (sustainable) dimasa datang, dan memiliki keterkaitan antar sektor usaha maupun antar wilayah.

Organisasi Pengelolaan Inisiasi Anti Poverty Program (APP) Jawa Timur tahun 2005 dikoordinasikan oleh Tim Pembina Propinsi yang diketuai oleh Kepala Bappeprop Jawa Timur dengan Anggota Tim Pembina dari Dinas Teknis Propinsi Jawa Timur (SK Gubernur Nomor : 118/245/KPTS/013/2005).Inisiasi Anti Poverty Program (APP) dilaksanakan oleh Satuan Kerja (SATKER) di Tingkat Propinsi dengan jenis kegiatan disesuaikan bidang tugas pokok, fungsi Satuan Kerja dan kebutuhan masyarakat yang menjadi sasaran.

Sendi utama dari program APP ini adalah Partnership atau Kemitraan. Kemitraan adalah suatu strategi bisnis yang dilakukan oleh dua pihak atau lebih dalam jangka waktu tertentu untuk meraih keuntungan bersama dengan prinsip saling membutuhkan dan saling membesarkan. Karena merupakan suatu strategi bisnis maka keberhasilan kemitraan sangat ditentukan oleh adanya kepatuhan di antara yang bermitra dalam menjalankan etika bisnis. Dalam konsteks ini pelakupelaku yang terlibat langsung dalam kemitraan tersebut harus memiliki dasar-dasar etika bisnis yang dipahami dan dianut bersama sebagai titik tolak dalam menjalankan kemitraan (Mariotti, 1999). Oleh karena itu, tujuan kemitraan usaha adalah meningkatkan nilai tambah atau keuntungan bagi pelaku agribisnis yang melaksanakan kemitraan berupa peningkatan pendapatan, kesinambungan usaha, peningkatan sumber daya manusia petani-nelayan, peningkatan volume usaha, menyerapkan tenaga kerja, jaminan ketersediaan bahan baku maupun daya saing komoditas pertanian (Baharsjah, 1997).

Agar tujuan kemitraan dapat terwujud, maka pola hubungan kerja yang bercirikan kemitraan usaha perlu ditumbuh-kembangkan. Dengan menumbuh-kembangkan kesetaraan diantara pelaku kemitraan dapattercipta melalui dua cara yaitu :

1. Cara alami yang terjadi pada kegiatan usaha yang produk dan pola usahanya memungkinkan terjadinya kemitraan berdasarkan fungsi masing - masing.

2. Cara non alami ditempuh melalui penguatan sisi pelaku yang lemah dengan bantuan berbagai kebijaksanaan yang dikeluarkan oleh pemerintah.

Dalam era ekonomi global dimana mekanisme pasar menjadi acuan semua pelaku ekonomi, maka kata kunci yang menjadi indikator keunggulan adalah produktivitas. Secara umum produktivitas didefinisikan dalam model ekonomi sebagai output dibagi dengan input. Dengan kata lain produktivitas akan meningkat apabila dengan input yang sama dapat memperoleh hasil 
yang lebih tinggi atau sebaliknya dengan tingkat hasil sama hanya membutuhkan input yang lebih rendah (Yujiro Hayami, et al. 1987).

Peningkatan produktivitas diharapkan dapat dirasakan oleh pihak pihak yang bermitra (Nasution, 2002). Bagi perusahaan besar, peningkatan produktivitas dapat dilakukan dengan duacara. Pertama, tingkat produksi yang diharapkan dapat dicapai dengan mengurangi faktor input, misalnya target penjualan dapat dicapai dengan pengurangan tenaga kerjja di lapangan yang dimiliki oleh perusahaan, yaitu dengan menerapkan model pemasaran berjenjang (multilevel marketing). Kegiatan pemasaran dilapangan dilakukan oleh pemasar lepas atau perusahaan mandiri. Disektor pertanian, model ini dilaksanakan dalam pola PIR. Perusahaan besar dapat mengoperasionalkan kapasitas pabriknya secara sendiri, karena biaya untuk keperluan tersebut ditanggung oleh petani plasma peserta program PIR (Sukartawi, 1999; Soeharjo, 1991).

Cara kedua, peningkatan produktivitas bagi perusahaan besar dilakukan dengan cara meningkatkan produksi (output) dengan menggunakan sumberdaya sendiri yang sama / tetap baik jumlah maupun kualitas. Contoh ini diambil dari modal usaha waralaba. Perusahaan induk (pemilik nama) dapat meningkatkan pangsa pasarnya tanpa harus membiayai sendiri pembukaan cabangcabang barunya (Limbong dan Sitorus, 1985; Soeharjo, 1991).

Bagi perusahaan kecil / petani secara individu, peningkatan produktivitas biasanya dipakai secara simultan yaitu dengan cara menambah unsur input baik kualitas maupun kuantitas dalam jumlah tertentu tetapi akan diperoleh output dalam dan kualitas yang berlipat.

Secara berkelompok, pihak perusahaan kecil/petani dapat pula meningkatkan produktivitasnya dengan cara mengurangi/menekan faktor input. Hal ini dapat terjadi pada faktor input yang dapat digunakan secara bersama seperti alat pengolahan tanah menggunakan traktor milik kelompok, memberantas hama penyakit, pemeliharaan irigasi, pengangkutan apabila dilakukan dalam jumlah yang besar (Sukartawi, 1985). Program Anti Kemiskinan dapat digambarkan sebagai berikut:

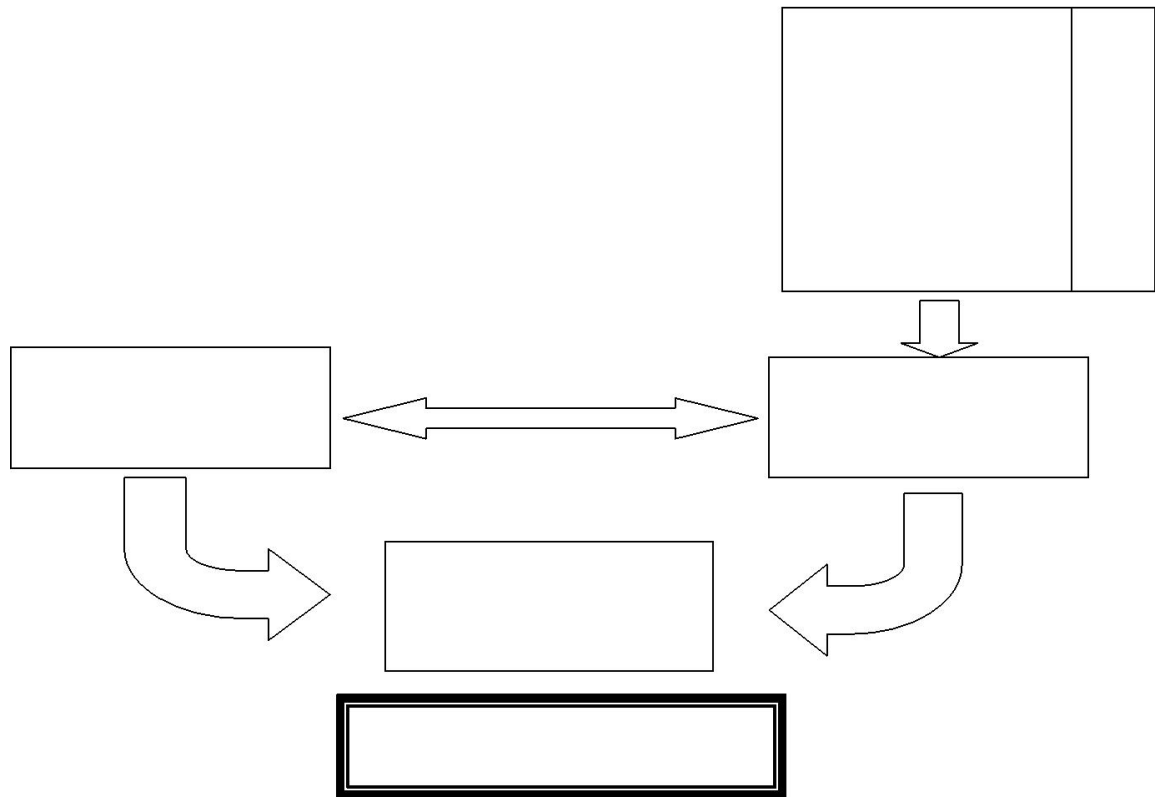

Gambar 1. Kerangka Pikir 


\section{METODE PENELITIAN DAN ANALISIS DATA}

\section{Populasi dan Sampee}

Sejalan dengan program APP yang bertujuan untuk mengatasi kemiskinan petani, maka populasi dari studi ini adalah petani miskin. Oleh karena pendekatan APP ini adalah kemitraan, maka sample dari studi ini adalah kelompok tani miskin Karya Makmur di daerah Pacitan yang sudah melaksanakan program ini. Berdasarkan pengalamannya, studi ini akan mengevaluasi program APP dari beberapa sudut pandang. Dari sifat studi ini seperti yang digambarkan di atas, maka data yang dikumpulkan adalah data primer yang diambil langsung dari petani atau kelompok tani target dalam bentuk catatan catatan historis, maupun inverview (in-depth).

\section{Teknik Analisis dan Penolahan Data Analisis deskriptif kualitatif}

Analisis deskripsi kualitatif digunakan untuk menguraikan dan mencari pola pola dalam persepsi petani tentang hal hal yang baik dan yang kurang baik dari program yang dilakukan tersebut. Deskriptif kualitatif ini lebih banyak menguraikan narasi dari para nara-sumber yang menyangkut pengalaman mereka baik yang dipikirkan, dirasakan, dihayati baik itu merupakan hal hal yang menyenangkan mereka maupun yang tidak mereka sukai. Selanjutnya analisis ini juga akan menemukan harapan harapan ke depan dari program ini yang dikehendaki oleh para petani. Analisis ini dilakukan setelah dan selama pengumpulan data yang bersifat interaktif, terbuka, dan mendalam.

\section{Analisis Uji Beda}

Analisis uji beda digunakan untuk menjawab tujuan kedua yaitu apakah ada perbedaan pendapatan anggota kelompok masyarakat sebelum dan sesudah menerima Program Anti Kemiskinan digunakan uji beda rata-rata dengan rumus (Saleh, 1992):

$$
t=\frac{\bar{X}_{a f}-\bar{X}_{b f}}{S D_{\bar{X}_{a f}-\bar{X}_{b f}}}
$$

\section{Dimana :}

$\overline{\mathrm{X}}_{\mathrm{bf}}$ adalah nilai rata rata sebelum diterapkan APP

$\overline{\mathrm{X}}_{\mathrm{af}}$ adalah nilai rata rata setelah diterapkan APP

$\mathrm{SD}_{\overline{\mathrm{X}}_{\mathrm{bf}}}-\overline{\mathrm{X}}_{\mathrm{gf}}$ adalah standar deviasi dari beda rata rata tersebut

Test $\mathrm{t}$ akan diuji dengan derajat kesalahan alpha (a) $5 \%$.

Dengan kaidah pengujian:

1. Bila thitung $>t$ tabel pada á 0,05 berarti pendapatan masyarakat sesudah menerima Program Anti Kemiskinan berbeda nyata dengan pendapatan masyarakat sebelum menerima Program Anti Kemiskinan

2. Bila t hitung $<\mathrm{t}$ tabel pada á 0,05 berarti pendapatan masyarakat sesudah menerima Program Anti Kemiskinan tidak berbeda nyata dengan pendapatan masyarakat sebelum menerima Program Anti Kemiskinan (Suparmoko, 1999).

Dengan menggunakan catatan historis tentang produksi dan pendapatan mereka dahulu dan sekarang, maka lewat formula uji beda dapat disimpulkan apakah terjadi perbedaan yang signifikan pada produksi dan pendapatan yang telah dialami para petani. 


\section{Analisis SWOT}

Untuk menjawab tujuan ketiga tentang faktor faktorr pengaruh baik internal maupun eksternal, digunakanlah analisis SWOT (Rangkuti, 2001). Analisis SWOT adalah analisis untuk mengidentifikasi tentang kekuatan (strength), kelemahan (weakness), peluang (opportunities) dan ancaman (treath) bagi strategi peningkatan pendapatan anggota kelompok masyarakat melalui Program Anti Kemiskinan. Dalam analisis ini data dibedakan menjadi dua yaitu data internal dan data eksternal. Selanjutnya data tersebut dianalisis dengan Analisis Strategi Faktor Eksternal (EFAS) dan Analisis Strategi Faktor Internal (IFAS).

\section{HASIL DAN PEMBAHASAN}

\section{Tanggapan Petani Terhadap Program Anti Kemiskinan}

Dengan keterbatasan modal yang dimiliki sebagian besar petani, sehingga dalam penggunaan paket teknologi pertanian yangdalam hal ini adalah intensifikasi pertanian kebanyakan dibawah tingkat yang dianjurkan, sehingga produktivitas usaha di bidang pertanian sangat jauh dari harapan.

Dalam kondisi permodalan anggota kelompok tani Karya Makmur di Kabupaten Pacitan yang pada umumnya rendah, keberadaan Program Anti Kemiskinan dalam rangka mengentaskan kemiskinan dengan menggunakan konsep sistem agribisnis, mulai dari agroinput sampai pemasaran sangatlah menunjang keberhasilan kelompok tani dalam meningkatkan pendapatannya, Dengan program anti Kemiskinan yang memberikan modal bantuan berupasarana produksi pada kelompok tanisehingga dapat menunjang meningkatkan pengelolaan sumberdaya produksi yang dimilikioleh petani, disamping itu penerima program ini mensyaratkan petani berkelompok dan memiliki kelembagaan, dengan demikian maka terjadi efisiensi dan efektivitas usaha tani, disamping itu program anti kemiskinan juga memberikan akses pasar, dengan memberikan pinjaman lunak bagi mitra usaha kelompok tani karya makmur, dengan konsekuensi bahwa mitra usaha akan membeli produk kelompok tani karya makmur.

Kurangnya permodalan bagi kelompok tani kebanyakan, menunjukkan indikasi bahwa peningkatan produktivitas akan sulit dicapai. Penggunaan teknologi yang tepat (teknologi tepat guna) akan memberikan hasil yang optimal jika anjuran dalam berusahatani dijalankan dengan benar dan keberhasilan dalam berusaha tani juga sangat bergantung dengan ketersediaan modal usaha yang memadai.

Pentingnya bantuan modal usaha disebabkan oleh kenyataan bahwa kemampuan permodalan usaha yang dimilikipetani sebagian masihrendah. Sedangkan dengan dengan kemampuan modal usaha yang rendah maka intensifikasi pertanian akan sangat sulit dilaksanakan, artinya bahwa proses peningkatan produksi akan sulit tercapai, sehingga program anti kemiskinan ini prinsipnya adalah pemerintah daerah memberikan modal usaha pada kelompok tani yang telah eksis berusaha tani berupa sarana produksi yang berkualitas, difasilitasi pemasarannya kemitra usaha, danmitra usaha diberikan pinjaman dengan bunga rendah dengan konsekuensi harus membeli produk Tabel 1. Tanggapan Petani Terhadap Program Anti Kemiskinan.

\begin{tabular}{llcc}
\hline No & Tanggapan Petani & $\begin{array}{c}\text { Jumlah } \\
\text { (Jiwa) }\end{array}$ & $\begin{array}{c}\text { Prosentase } \\
\text { (\%) }\end{array}$ \\
1 $\quad$ Meningkatkan produksi dan pendapatan & & \\
Alasan : & 21 & 48,84 \\
a. Meningkatkan kemampuan modal & 15 & 34,88 \\
b. Dukungan motivasi & & \\
2. Mempermudah proses pemarsaran & 26 & 60,47 \\
Alasan : & 16 & 37,21 \\
a. Harga cukup baik & & \\
b. Tidak terdapat permainan harga & 13 & 30,23 \\
Tidak meningkatkan pendapatan & & \\
Alasan : & & \\
a. bantuan yang diberikan terlalu kecil & & \\
\hline
\end{tabular}


kelompok tani dengan harga pasar / harga yang wajar. Adapun tanggapan anggota kelompok tani Karya Makmur di Kabupaten Pacitan terhadap Program Anti Kemiskinan terlihat pada tabel 1.

Tabel di atas menunjukkan bahwa $83,72 \%$ petani menyatakan bahwa pemberian bantuan modal usaha dapat meningkatkan produksi dan pendapatan yang diterima dalam kegiatan usahatani. Hal ini tidak terlepas dari :

1. Bantuan modal usaha diberikan dapat meningkatkan kemampuan modal kelompok tani $(48,84 \%)$ yang pada gilirannya akan meningkatkan kemampuan berusaha dalam menjalankan usaha taninya dengan tujuan dapat meningkatkan produksi. Pemberian bantuan berupa sarana produksi dalam program anti kemiskinan ini agar terjadi peningkatan penggunaan faktor produksi yaitu sarana produksi dan merupakan bagian dari modal tidak tetap yaitu :

a. Modal mempunyai sifat produktif, yaitu meningkatkan kapasitas usaha yang produktif.

b. Modal memiliki sifat prospektif, yaitu meningkatkan produktivitas usaha dikemudian hari. Sifat ini terwujud apabila sebagian pendapatan yang diterima hari ini dapat disisihkan.

2. Bantuan yang diberikan kepada kelompok tani disertai oleh pembinaan dan bantuan peningkatan pengetahuan melalui proses pendampingan oleh tenaga yangterlatih dan profesional sehingga dapat memberikan motivasi peningkatan produksi $(34,88 \%)$ yang juga didukung oleh penyediaan kebutuhan sarana produksi seperti kebutuhan kelompok tani akan pupuk, benih dan sebagainya tersedia sehingga kelompok tani tidak merasa kekurangan sehingga kegiatan usaha tani dapatdilaksanakan dengan baik. Pada tabel 4. Juga menunjukkan 97,67 \% petani menyatakan bahwa program anti kemiskinan memberikan dampak terhadap kemudahan pada proses pemasaran yaitu dengan alasan bahwa harga cukup baik dan tidak adanya permainan harga. Kondisi tersebut sebenarnya tidak terlepas dari program anti kemiskinan yang telah mengkondisikan jalur kemitraan yang jelas dengan lembaga pemasaran yang dalam program ini disebut mitra usaha yang telah ada kesepakatan dalam menduung program anti kemiskinan yaitu meningkatkan kesejahteraan masyarakat padaumumnya dan petani pada khususnya.

Akan tetapi masih ada petani yaitu sebesar 30,23 \% yang menyatakan bahwa bantuan program anti kemiskinan tidak mendukung upaya meningkatkan produksi dan pendapatan usaha tani yang dilakukannya, hal ini karena bantuan yang diberikan terlalu kecil sehingga kurang memadai pada usaha tani yang dilakukannya. Kondisi ini, sebenarnya terjadi karena kepemilikan lahan yang sempit sehingga bantuannyapun tidak banyak yang diterima.

\section{Perbedaan Pendapatan Angggota Kelompok Tani Sebelum dan Sesudah Menerima Program Anti Kemiskinan}

Perbedaan pendapatan anggota kelompok tani karya makmur sebelum dan setelah menerima bantuan Program Anti Kemiskinan dapat menjadikan suatu indikator apakah keberadaan program anti kemiskinan dapat meningkatkan pendapatan masyarakat sesuai dengan tujuan program anti kemiskinan atau tidak dapat meningkatkan pendapatan masyarakat.

Adapun tingkat pendapatan anggota kelompok tani sebelum dan setelah menerima program anti kemiskinan secara keseluruhan terlampir dalam lampiran 1 dan lampiran 2 yang menunjukkan kondisi antara lain :

1. Sebelum Program Anti Kemiskinan Rata - rata pendapatan per bulan sebesar Rp. 419.651,20

2. Setelah Program Anti Kemiskinan Rata - rata pendapatan per bulan sebesar Rp 531.395,30

3. Prosentase peningkatan pendapatan amggota kelompok tani Karya Makmurdi kabupaten Pacitan sesudah adanya Program Anti Kemiskinan yaitu (Rp. 531.395,30 - Rp.491.651) x $100 \%=21,03 \%$

Sedangkan hasil analisis perhitungan dengan menggunakan uji beda (uji t) menunjukkan bahwa nilai t hitung yaitu sebesar 8,542 dengan signifikansi sebesar 0,00 , artinya bahwa terdapat perbedaan 
pendapatan yang diterima petani petani anggota kelompok tani Karya Makmur di Kabupaten Pacitan sebelum dan setelah program anti kemiskinan.

\section{Faktor pengaruh Internal dan Eksternal Faktor Internal}

Pada analisis faktor - faktor internal ini terdiridari dua bagian yaitu kekuatan (strength) dan kelemahan (weakness) yang ada pada program anti kemiskinan terhadap peningkatan pendapatan petani pada Kelompok Tani Karya Makmur di kabupaten Pacitan dengan uraian sebagai berikut :

1. Kekuatan (Strength)

a. Manajemen Program Anti Kemiskinan cukup baik: Setiap organisasi selalu menggunakan manajemen dalam proses optimasi semua sumberdaya dalam pencapaian tujuan yang telah ditetapkan. Manajemen Program anti kemiskinan cukup baik yang telah mendapatkan bimbingan konsultan manajemen sehingga pengelolaan kelompok tani akan meningkat

b. Ketersediaan Dana: Ketersediaan modal kegiatan usaha sangatlah menunjang terhadap proses terlaksananya program anti kemiskinan yang telah diimplementasikan. Petani pada umumnya mempunyai modal yang sangat terbatas, sehingga membutuhkan bantuan modal usaha sehingga program anti kemiskinan ini cukup memadai untuk menunjang kegiatan usaha tani.

c. Ketrampilan anggota dalam bercocok tanam: Keterampilan anggota kelompok tani karya makmur sangat baik karena selain bercocok tanam merupakan pekerjaan sehari-hari dan turun temurun, sebagian dari anggota kelompok tani mendapatkan bimbingan dari penyuluh pertanian selama berpuluh - puluh tahun

d. Tersedianya alat bercocoktanam: tersedianya alat bercocok tanam, menjadi hal yang wajar karena mata pencaharian anggota kelompok tani adalah bercocok tanam, sehingga peralatan - peralatan tersebut telah tersedia

e. Perencanaan yang partisipatif: Sesuai dengan semangat inisiasi program anti kemiskinan dalam upaya pengentasan kemiskinan masyarakat perdesaan proses penyusunan kegiatan, proses pencairan bantuan, penyaluran dana, pelaksanaan program dan penyusunan laporan kegiatan, dilakukan secara partisipatif oleh anggota kelompok.

2. Kelemahan (Weakness)

a. Pendidikan petani rendah: Proses perubahan perilaku dari petani sangat dipengaruhi oleh tingkat pengetahuan yang dimiliki petani, dengan semakin tingginya tingkat pendidikan petani, maka semakin luas pula wawasan dari petani dalam menerima perubahan - perubahan yang dapat meningkatkan perolehan hasil usaha taninya.Tingkat pendidikan yang dimiliki oleh petani masih rendah sehingga tingkat kesadaran petani terhadap peningkatan produktivitas usaha juga masih rendah sehingga upaya peningkatan pendapatan dan kesejahteraan juga mengalami hambatan yang cukup berarti dalam menunjang keberhasilan inisiasi program anti kemiskinan.

b. Produktivitas petani rendah: Produktivitas petani rendah, kondisi tersebut tidak terlepas dari kondisi lemahnya tingkat permodalan petani, rendahnya tingkat pendidikan yang dimiliki petani dan kondisi budaya tradisional petani yang cukup mendukung terhadap peningkatan produktivitas sehingga kondisi tersebut merupakan kelemahan dari inisiasi program anti kemiskinandalam upaya meningkatkan pendapatan petani di Kelompok Tani Karya Makmur Kabupaten Pacitan.

c. Kemampuan modal petani rendah: Lemahnya permodalan petani, sudah merupakan ciri-ciri umum dari petani di Indonesia, sementara kegiatan usaha tani sangat membutuhkan permodalan yang cukup besar dari awal usaha yaitu proses pengolahan sampai proses pemanenan. Lemahnya permodalan petani tampak terlihat dalam proses penerapan intensifikasi yang kurang optimal sehingga produktivitas yang dihasilkan petani juga rendah. Kondisi tersebut merupakan kelemahan dari inisiasi program anti 


\section{Journal of Indonesian Applied Economics Vol. 3 No. 2 Oktober 2009, 121-134}

kemiskinan dalam upaya peningkatan pendapatan petani di kelompok tani makmur Kabupaten Pacitan.

d. Rendahnya akses pemasaran petani: Rendahnya akses pemasaran petani dalam memasarkan produk hasil panen tidak terlepas dari kondisi lokasi yang cukup jauh dari lokasi pasardan infrasturuktur yang kurang memadai. Selain itu juga keinginan untuk maju dan kutrangnya tingkat pengetahuan serta pendidikan petani yang rendah, ditambah lagi dengan peran tengkulak yang cukup dominan yang menjadikan kondisi petani menjadi lemah.

e. Lemahnya kelembagaan Kelompok Tani: Kelembagaan kelompok tani hanya merupakan bentuk kelompok yang kurang berperan dalam upaya mendukung anggota anggotanya untuk lebih maju, dalam hal pembukuan kegiatan usaha tani tidak diadministrasikan dengan baik, dengan kelembagaan kelompok tani yang kurang optimal tersebut merupakan kelemahan dari inisiasi program anti kemiskinan dalamupaya peningkatan pendapatan petani di Kelompok Tani Karya Makmur di Kabupaten Pacitan.

\section{Faktor Eksternal}

Pada analisis faktor - faktor internal ini terdiri dari dua bagian yaitu peluang (Oppurtunities) dan Kelemahan (Threat) yang ada pada inisiasi program anti kemiskinan terhadap peningkatan pendapatan petani di Kelompok Tani Karya Makmur Kabupaten Pacitan dengan uraian sebagai berikut :

1. Peluang (Oppurtunities)

a. Dukungan dari Pemerintah: Dukungan Pemerintah Daerah yang diberikan pada inisiasi program anti kemiskinan sangat besar, hal ini terkaitdengan upaya program peningkatan kesejahteraan masyarakat miskin yang berpotensi di pedesaan dalam rangka pengentasan kemiskinan, dukungan dari pemerintah daerah diantaranya adalah dukungan modal usaha tani, pendampingan dan bimbingan teknis serta akses pasar dan permodalan bagi mitra usaha. Besarnya dukungan pemerintah daerah merupakan peluang yang cukup besardalam rangka mengupayakan keberhasilan program anti kemiskinan yang bertujuan untuk meningkatkan kesejahteraan (pendapatan), mendukung sarana dan prasarana serta akses pasar bagi produk petani yang mendapatkan program ini.

b. Program pemberdayaan masyarakat: Inisiasi program anti kemiskinan merupakan program pemberdayaan masyarakat yang bukan hanya sekedar membantu pendanaan saja akan tetapi juga membangun struktur kelembagaan dan memfasilitasi akses sistem kemitraan dengan perusahaan serta membina kemandirian masyarakat dalam mengembangakan usahanya. Dengan kondisi tersebut diharapkan masyarakat mampu untuk meningkatkan produktivitasnya dan kemandiriannya melalui proses pendidikan dan pelatihan serta pembinaan dan pendampingan yang disertai dengan monotoring dan evaluasi hasil kerja.

c. Dukungan bersama dari instansi terkait: Inisiasi program anti kemiskinan digerakkan oleh berbagai level pemerintahan, dari tingkat propinsi, kabupaten/kota, kecamatan hingga desa serta keterlibatan aktif masyarakat, perbankan dan dunia usaha sehingga program ini mendapatkan dukungan yang luas yang merupakan peluang dari upaya pengentasan kemiskinan masyarakat, khususnya petanidi pedesaan. Kondisi tersebut tidak terlepas bahwa kerjasama yang merupakan bagian dari fungsi manajemen usaha yaitu membentuk suatu sistem yang dapat memberikan dukungan bagi keberhasilan program anti kemiskinan.

d. Pembentukan kemitraan dan akses pasar: Kemitraan yang baik merupakan salah satu kunci keberhasilan suatu usaha. Kemitraan yang dibentuk adalah dengan kelompok tani dengan mitra usaha. Kondisi tersebut tidak terlepas dari peran pemerintah daerah untuk memfasilitasi kelompok tani dengan mitra usaha (pasar), dengan harapan petani dapat memasarkan produknya dengan harga yang wajar kepada mitra usaha, sedangkan 
mitra usaha yang bersedia menampung produksi hasil kelompok tani penerima program anti kemiskinan disediakan dana pinjaman lunak dengan bunga yang rendah yang disediakan oleh Anggaran Pendapatan dan Belanja Daerah Propinsi JawaTimur, dengan kondisi yang demikian ini diharapkan program anti kemiskinan dapatberhasil meningkatkan pendapatan kelompok masyarakat miskin di pedesaan.

e. Dukungan Pinjaman lunak bagi mitra usaha: Program anti kemiskinan yang di Prakarsai oleh Pemerintah Propinsi Jawa Timur pada hakikatnya adalah memberi bantuan modal usaha kepala kelompok tani berupasarana produksi dan hasilnya di pasarkan kepada mitra usaha, mitra usaha ini diberikan bantuan berupa pinjaman lunak dengan bunga rendah, namun dengan konsekuensi bahwa mitra usaha harus membeli produk kelompok tani, dengan demikian peran mitra usaha sangat strategis karena merupakan kunci keberhasilan dalam pemasaran produk kelompok tani, sehingga dukungan pinjaman lunak yang difasilitasi oleh APBD Propinsi JawaTimur ini menjadikan peluang untuk berkembangnya program ini.

2. Ancaman (Treaths)

a. Akses Informasi: Akses informasi sangat minim berkaitan dengan informasi pertanian misalnya informasi harga komoditi pertanian, informasi pasar, informasi sarana produksi. Hal ini disebabkan karena daerah ini cukup terpencil sehingga petani menjual hasil produksinya disekitar lokasi budidaya dengan demikian harga yang diperoleh menjadi kurang maksimal

b. Kelangkaan Sarana Produksi: Kelangkaan sarana produksi seperti pupuk,obat-obatan yang terjadi didaerah lain juga terjadi di Kabupaten Pacitan, dengan daerah yang relatif julit dijangkau dari daerah lain, sehingga didaerah ini apabila terjadi kelangkaan tentu akan lebih sulit mengatasinya.

c. Persaingan Usaha: Masih tingginya tingkat kemiskinan diperdesaan menyebabkan kurangnya daya juang untuk bersaing dalam berusaha.

d. Sarana Transportasi yang kurang memadai: Sarana transportasi yang kurang memadai, menjadi ancaman yang serius bagi usaha tani pada kelompok tani karya makmur karena menyebabkan cost produksi yang tinggi.

e. Sarana Jalan: Didaerah penelitian akses jalan kurang memadai, sehingga kurang mendukung kegiatan ekonomi.

\section{E. KESIMPULAN DAN REKOMENDASI}

Berdasarkan hasil penelitian strategi program anti kemiskinan terhadap peningkatn pendapatan petani di kelompok tani karya makmur Kabupaten Pacitan, dapat disimpulkan sebagai berikut :

1. Tanggapan petani terhadap program anti kemiskinan cukup positif dengan alasan sebagian besar petani menyatakan bahwa program anti kemiskinan dapat meningkatkan produksi pertanian dan sebagian kecil petani menyatakan program anti kemiskinan tidak meningkatkan produksi dan pendapatan dengan alasan bantuan yang diberikan terlalu kecil.

2. Terdapat perbedaan pendapatan anggota kelompok tani sebelum dan sesudah menerima program anti kemiskinan dengan prosentase peningkatan pendapatan anggota kelompok tani karya makmur di kabupaten Pacitan setelah program anti kemiskinan sebesar 21,3\%

3. Strategi yang tepat dan perlu dilakukan adalah strategi agresif yakni menggunakan seluruh kekuatan untuk memanfaatkan peluang yang dimiliki. 
Journal of Indonesian Applied Economics

Vol. 3 No. 2 Oktober 2009, 121-134

\section{DAFTAR PUSTAKA}

Baharsjah, 1997. Pengembangan Agribisnis di Indonesia. Departemen Pertanian, Jakarta.

Downey dan Erickson, 1987. Manajemen Agribisnis. Terjemahan Rochidayat dan Sirait. Penerbit Erlangga, Jakarta.

Limbong, W. H. dan Panggabean Sitorus, 1985. Pengantar Tata Niaga Pertanian. Jurusan Ilmu Ilmu Sosial Ekonomi Pertanian Fakultas Pertanian. Institut Pertanian Bogor.

Mariotti, John L, 1999. The Power of Partnership , Blackwell Publisher, Massachusset, USA

Nasution Muslimin, 2002. Peran Koperasi Sebagai Pusat Pelayanan Ekonomi Pedesaan, Departemen Koperasi, Jakarta.

Rangkuti, 2001. analisis SWOT Teknik Membedah Kasus Bisnis PT. Gramedia Pusaka Utama, Jakarta.

Saleh, Samsubar, 1992. Statistic Induktif. Unit Penerbit dan Percetakan AMP YKPN. Jogyakarta.

Soeharjo A., 1991. Kumpulan Makalah Agribisnis, Magister manajemen Agribisnis, Institut Pertanian Bogor. Bogor.

Sukartawi, 1985. Pembangunan Pertanian, LP3ES.

Sukartawi, 1999. Agribisnis Teori dan Aplikasinya, Edisi I cetakan 5. PT. Raja Grafindo Persada, Jakarta

Suparmoko, 1999. Metode penelitian Praktis. BPFE, Jogjakarta

Yujiro Hayami, et al. 1987. Agricultural Marketing and Processing in Upland java. A Perspective From A Sunda Village. CGPRT. Bogor. 
Lampiran:

Matrik Pembobotan IFAS dan EFAS

Tabel 2. Matrik Pembobotan, Rating dan Skor untuk Faktor - Faktor Internal Program Anti Kemiskinan Terhadap Peningkatan Pendapatan Petani di Kelompok Tani Karya Makmur Kabupaten Pacitan.

\begin{tabular}{c|l|cc|c}
\hline No & \multicolumn{1}{|c|}{ Faktor Internal } & Bobot & Rating & Skor \\
\hline A & \multicolumn{1}{|c}{ KEKUATAN } & & & \\
\hline 1 & Manajemen program cukup baik & 0.13 & 3 & 0.38 \\
2 & Ketersediaan dana & 0.14 & 3 & 0.41 \\
3 & Ketrampilan anggota dalam bercocoktanam & 0.12 & 3 & 0.36 \\
\hline 4 & Tersedianya alat bercocok tanam & 0.13 & 3 & 0.38 \\
\hline 5 & Perencanaan partisipatif & 0.13 & 3 & 0.39 \\
\hline & & & & 1.91 \\
B & KELEMAHAN & & & \\
1 & Pendidikan petanirendah & 0.07 & 2 & 0.14 \\
\hline 2 & Produktivitas petani rendah & 0.07 & 2 & 0.14 \\
\hline 3 & Kemampuan modal petani rendah & 0.08 & 2 & 0.23 \\
\hline 4 & Rendahnya akses pemasaran petani & 0.08 & 2 & 0.23 \\
\hline 5 & Lemahnya kelembaganan kelompok tani & 0.06 & 2 & 0.23 \\
& & & & 0.85 \\
\hline
\end{tabular}

Tabel 3. Matrik Pembobotan, Rating dan Skor untuk Faktor - Faktor Eksternal Program Anti Kemiskinan Terhadap Peningkatan Pendapatan Petani di Kelompok Tani Karya Makmur Kabupaten Pacitan.

\begin{tabular}{|l|l|ll|l}
\hline No & Faktor Eksternal & Bobot & Rating & Skor \\
\hline A & PELUANG & & & \\
\hline 1 & Dukungan dari pemerintah & 0.13 & 3 & \\
2 & Program pemberdayaan masyarakat & 0.13 & 3 & 0.40 \\
3 & Dukungan bersama dari instansi terkait & 0.13 & 3 & 0.40 \\
\hline 4 & Pembentukan kemuitraan dan akses pasar & 0.12 & 3 & 0.40 \\
\hline 5 & Dukungan pinjaman lunak bagi mitra usaha & 0.15 & 3 & 0.36 \\
\hline & & & & 0.44 \\
B & ANCAMAN & & & \\
1 & Kurangnya informasi & 0.07 & 2 & \\
\hline 2 & Kelangkaan Sarana Produksi & 0.08 & 3 & 0.13 \\
\hline 3 & Persaingan Usaha & 0.06 & 2 & 0.24 \\
\hline 4 & Sarana transportasi kurang memadai & 0.06 & 2 & 0.12 \\
\hline 5 & Sarana jalan kurang menunjang & 0.07 & 2 & 0.12 \\
\hline
\end{tabular}


Perumusan Strategi

Tabel 4. Matrik SWOT

\begin{tabular}{|c|c|c|}
\hline EFAS & $\begin{array}{l}\text { STRENGTHS (S) } \\
\text { 1. Manajemen Program cukup baik } \\
\text { 2. Ketersediaan dana } \\
\text { 3. Ketrampilan bercocoktanam } \\
\text { 4. Tersedianya alat bercocoktanam } \\
\text { 5. Perencanaan partisipatif }\end{array}$ & 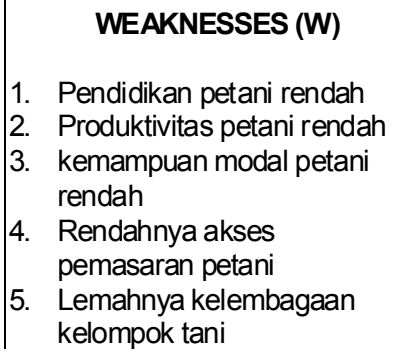 \\
\hline $\begin{array}{l}\text { OPPORTUNITIES (O) } \\
\text { 1. Dukungan dari pemerintah. } \\
\text { 2. Program pemberdayaan } \\
\text { masyarakat } \\
\text { 3. Dukungan bersama dari } \\
\text { instansi terkait } \\
\text { 4. Pembentukan kemitraan dan } \\
\text { akses pasar } \\
\text { 5. Dukungan pinjaman lunak } \\
\text { bagi mitra usaha }\end{array}$ & $\begin{array}{l}\text { STRATEGI SO } \\
\text { 1. Peningkatan kemandirian petani } \\
\text { melalui pembinaan dan penyuluhan. } \\
\text { 2. Pengembangan kemitraan pada } \\
\text { kegiatan agroindustri dalam upaya } \\
\text { menambah nilai tambah produksi } \\
\text { 3. Pemberdayaan masyarakat dalam } \\
\text { upaya peningkatan ekonomi dengan } \\
\text { memanfaatkan pinjaman lunak }\end{array}$ & 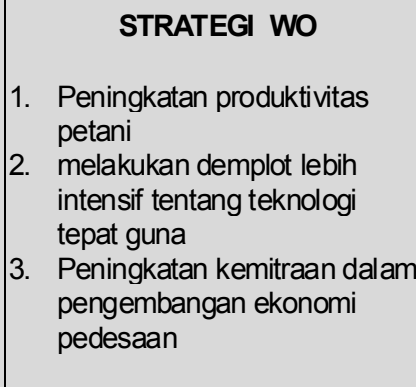 \\
\hline $\begin{array}{l}\qquad \text { TREATHS (T) } \\
\text { 1. Informasi } \\
\text { 2. Kelangkaan saprodi } \\
\text { 3. Persaingan usaha } \\
\text { 4. Sarana transportasi kurang } \\
\text { memadai } \\
\text { 5. Sarana jalan kurang } \\
\text { memadai }\end{array}$ & $\begin{array}{l}\text { STRATEGI ST } \\
\text { 1. Pengembangan usaha kelompok tani } \\
\text { 2. membuka dan memperkuat jaringan } \\
\text { pasar baru } \\
\text { 3. memberikan kepastian jaminan usaha } \\
\text { yang dilakukan petani }\end{array}$ & $\begin{array}{l}\text { STRATEGI WT } \\
\text { 1. Peningkatan penggunaan } \\
\text { teknologi melalui pembinaan } \\
\text { dan penyuluhan. } \\
\text { 2. Pemberdayaan masyarakat } \\
\text { dalam upaya menciptakan } \\
\text { lapangan kerja baru }\end{array}$ \\
\hline
\end{tabular}

Alternatif strategi dari program anti kemiskinan dalam peningkatan pendapatan petani di kelompok tani karya makmur Kabupaten Pacitan berdasarkan analisis matrik SWOT tersebut sebagai berikut :

1. Strategi S - O

Strategi ini dibuat dengan menggunakan seluruh kekuatan untuk memanfaatkan peluang yang dimiliki program anti kemiskinan terhadap peningkatan pendapatan petani di kelompok tani karya makmurKabupaten Pacitan yang diformulasikan alternatif strategi sebagai berikut :

a. Peningkatan kemandirian petani melalui pembinaan dan penyuluhan.

b. Pengembangan kemitraan pada kegiatan agroindustri dalam upaya menambah nilai tambah produksi

c. Pemberdayaan masyarakat dalam upaya peningkatan ekonomi dengan memanfaatkan pinjaman lunak

\section{Strategi $\mathrm{S}-\mathrm{T}$}

Strategi ini menggunakan kekuatan yang dimiliki program anti kemiskinan terhadap peningkatan pendapatan petani di kelompok tani karya makmur Kabupaten Pacitan dengan meminimalkan ancaman yang dimiliki. Berdasarkan identifikasi terhadap kekuatan internal dan ancaman eksternal, diformulasikan alternatif strategi sebagai berikut :
a. Pengembangan usaha kelompok tani
b. membuka dan memperkuat jaringan pasar baru
c. memberikan kepastian jaminan usaha yang dilakukan petani 
3. Strategi $\mathrm{W}-\mathrm{O}$

Strategi ini diterapkan berdasarkan pemanfaatan peluang yang ada dengan cara mengatasi kelemahan - kelemahan yang dimiliki melalui aktivitas meminimalkan kelemahan dan memanfaatkan peluang, yang diformulasikan alternatif strategi sebagai berikut :

a. Peningkatan produktivitas petani

b. melakukan demplot lebih intensif tentang teknologi tepat guna

c. Peningkatan kemitraan dalam pengembangan ekonomi pedesaan

\section{Strategi $\mathrm{W}-\mathrm{T}$}

Kondisi ini sangat tidak menguntungkan karena terjadi ancaman dari lingkungan eksternal dan kelemahan dari lingkungan internal, maka diformulasikan alternatifstrategi sebagai berikut:

a. Peningkatan penggunaan teknologi melalui pembinaan dan penyuluhan.

b. Pemberdayaan masyarakat dalam upaya menciptakan lapangan kerja baru

Dari uraian faktor - faktor kekuatan, kelemahan, peluang dan ancaman dari analisis SWOT dengan pembobotan, maka secara singkat dapat disajikan kedalam matrik pembobotan analisis SWOT sebagai berikut :

Tabel 5. Matrik Pembobotan Analisis SWOT

\begin{tabular}{l|r|l|r}
\hline \multicolumn{1}{c|}{ Strengths/Kekuatan } & Skor & \multicolumn{1}{|c}{ Weaknesses/Kelemahan } & Skor \\
\hline Manajemen Program cukup baik & 3,33 & Pendidikan petani rendah & 1,83 \\
\hline Ketersediaan dana & 3,67 & Produktivitas petani rendah & 1,83 \\
\hline $\begin{array}{l}\text { Ketrampilan anggota dalam bercocok } \\
\text { tanam }\end{array}$ & 3,17 & kemampuan modal petani rendah & 2,00 \\
\hline Tersedia alat bercocoktanam & 3,33 & Rendahnya akses pemasaran & 2,00 \\
\hline Perencanaan partisipatif & 3,50 & Lemahnya kelembagaan kelompok tani & 2,00 \\
\hline Jumlah & 17,00 & Jumlah & 9,67 \\
\hline \multicolumn{1}{|c|}{ Opportunities/Peluang } & Skor & Threats/Ancaman & Skor \\
Dukungan dari pemerintah. & 3,33 & Informasi & 1,67 \\
Program pemberdayaan masyarakat & 3,33 & Kelangkaan saprodi & 2,00 \\
\hline Dukungan bersama dari instansi terkait & 3,33 & Persaingan usah & 1,50 \\
\hline $\begin{array}{l}\text { Pembentukan kemitraan dan akses } \\
\text { pasar }\end{array}$ & 3,00 & Sarana transport kurang memadai & 1,83 \\
$\begin{array}{l}\text { Dukungan pinjaman lunak bagi mitra } \\
\text { usaha }\end{array}$ & 3,67 & Sarana jalan kurang memadai & 1,83 \\
\hline Jumlah & 16,67 & Jumlah & 8,83
\end{tabular}

Tabel 5. dapat diketahui bahwa bobot masing - masing variabel adalah Strengths $/$ Kekuatan $=$ 17,00; Weaknesses / Kelemahan = -9,67; Opportunities $/$ Peluang =16,67; dan Threats / Ancaman $=-8,83$, variabel Weaknesses / Kelemahan dan Threats / Ancaman merupakan suatu keadaan yang akan mengurangi daya saing program anti kemiskinan terhadap peningkatan pendapatan petani di kelompok tani Karya MakmurKabupaten Pacitan sehingga nilainya negatif. Dari diagram SWOT dapat diketahui bahwa titik P yaitu dimana unit program anti kemiskinan terhadap peningkatan pendapatan petani di kelompok tani karya makmur Kabupaten Pacitan berada dan hal ini dapat dijadikan pedoman dalam pemilihan strategi sesuai dengan kuadran dimana titik itu berada seperti disajikan pada Gambar 2. 


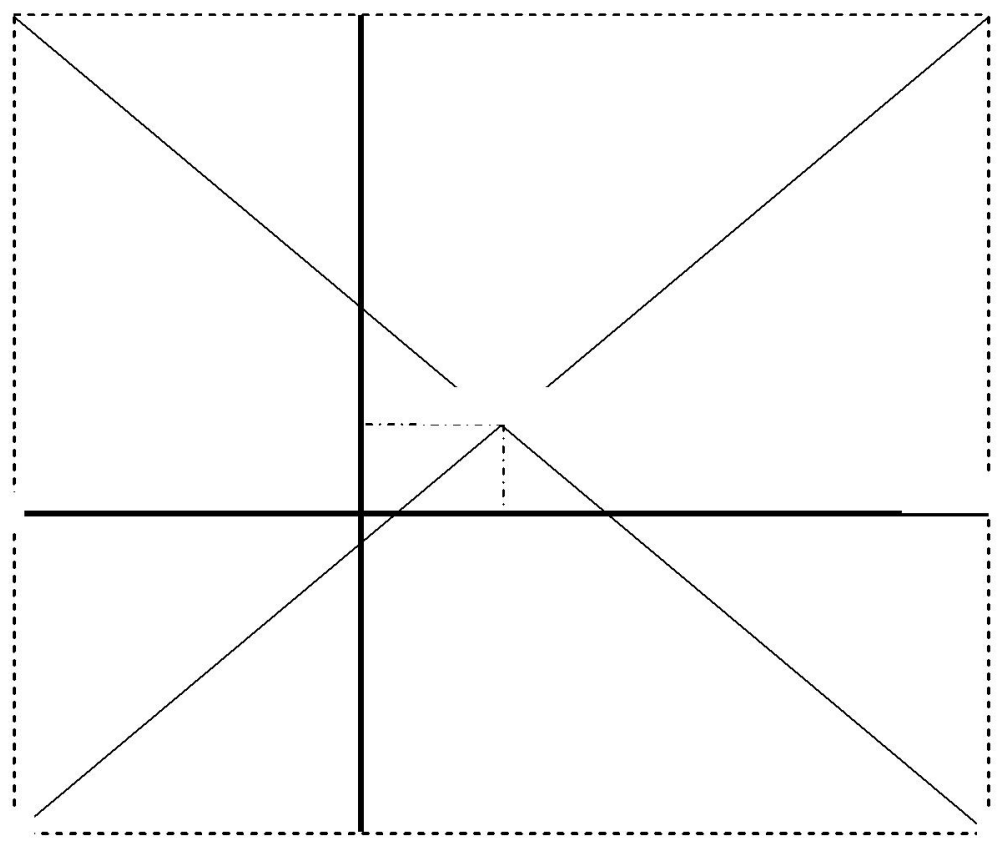

Gambar 2. Titik Posisi (P) Program Anti Kemiskinan Terhadap Peningkatan Pendapatan Petani di Kelompok Tani Karya Makmur Kabupaten Pacitan

Gambar 2. menunjukkan bahwa posisi Program anti kemiskinan terhadap penongkatan pendapatan petani di kelompok tani karya makmur Kabupaten Pacitan berada pada kuadran I atau strategi yang dibuat dengan menggunakan seluruh kekuatan untuk memanfaatkan peluang yang dimiliki program anti kemiskinan yaitu strategi agresif. 